\title{
Brucellosis mimicking prostate cancer: Case report and review of the literature
}

\section{Prostat kanserini taklit eden bruselloz: Olgu sunumu ve literatür taraması}

\author{
Lütfi CANAT ${ }^{1}$, Akif ERBiN², Hasan Tahsin GÖZDAŞ ${ }^{3}$, Hasan Anıl ATALAY ${ }^{1}$
}

\section{ABSTRACT}

Brucella has been reported to infect the central nervous system, gastrointestinal system, musculoskeletal system, and genitourinary system. Prostatitis is a very rare complication of brucellosis. A case of a 49-year-old man who presented with bladder outlet obstruction and dysuria was reported. The patient's signs were mimicking the prostate cancer (such as elevated prostate-specific antigen levels, abnormal digital rectal examination). The patient's Brucella agglutination test was positive at 1/640 titer and doxycycline and rifampin was administered over 6 weeks. One month after cessation of the therapy, patient's signs mimicking those of prostate cancer were normal and the patient was followed-up for 12 months and no relapse was observed. It should not be forgotten that acute prostatitis may develop after brucellosis. Moreover, brucella prostatitis may mimic prostate carcinoma.

Keywords: Brucellosis, prostate cancer, prostate-specific antigen, prostatitis, Wright agglutination test öz

Brusellanın, merkezi sinir sistemi, gastrointestinal sistemi, iskelet-kas sistemini ve genitoüriner sistemi tuttuğu rapor edilmiştir. Prostatit ise brusellozun çok ender görülen bir komplikasyonudur. Bu çalışmada, mesane çıkışı darlığı ve dizüri nedeniyle başvuran 49 yaşındaki erkek hasta sunulmuştur. Hastanın bulguları (yükselen PSA, anormal parmakla rektal muayene) prostat kanserini taklit etmektedir. Hastanın Brusella aglütinasyon testi 1/640 titrede pozitif bulunmuştur ve 6 hafta süreyle doksisiklin ve rifampin tedavisi başlanmıştır. Tedavi bitiminden 1 ay sonra hastanın prostat kanserini taklit eden bulguları normale dönmüş ve 12 aylık takip sonucu relaps izlenmemiştir. Brusellozis sonrası akut prostatit gelişebiliceği unutulmamalıdır. Dahası, brusella prostatiti prostat kanserini taklit edebilir.

Anahtar kelimeler: Bruselloz, prostat kanseri, prostat spesifik antijen, prostatit, Wright aglütinasyon testi

\section{INTRODUCTION}

Brucellosis is one of the most common zoonotic diseases in the world. In Turkey brucellosis is an endemic disease and seropositivity rate is $1.8 \%$ in the healthy population and its incidence is 0.59 per $100.000^{1}$. The clinical characteristic of brucellosis are not disease specific; every organ can be affected. Brucella has been reported to compromise the central nervous system, the gastrointestinal system, musculoskeletal system, and genitourinary system ${ }^{2}$. Genitourinary system complications such as epididymo-orchitis, prostatitis, glomerulonephritis and renal abscesses can be found in about $1-22 \%$ of the patients ${ }^{3}$. Unilat- eral epididiymoorchitis is the usual manifestation of genitourinary involvement due to brucellosis. Acute prostatitis is a rare complication of brucellosis. Additionally, there are no certain guidelines related to the choice of antibiotic treatment and management the disease ${ }^{4-6}$. We have chosen to report this case because prostatitis is a rare presentation of brucellosis mimicking prostate cancer.

\section{CASE REPORT}

A 49 year-old male patient who is dealing with the livestock sector, with no previously known disease, had for the last one month complaints of bladder

Received: 13.03 .2017

Accepted: 15.05 .2017

${ }^{1}$ Department of Urology, Okmeydanı Training and Research Hospital, İstanbul, Turkey

${ }^{2}$ Department of Urology, Haseki Training and Research Hospital, İstanbul, Turkey

${ }^{3}$ Department of Infectious Diseases, Kastamonu State Hospital, Kastamonu, Turkey

Yazışma adresi: Lütfi Canat, Department of Urology, Okmeydanı Training and Research Hospital, i̇stanbul, Turkey

e-mail:drhlcaat@gmail.com 
outlet obstruction and dysuria. Physical examination revealed, International Prostate Symptom Score (IPSS) of 20 , prostate volume on transrectal ultrasonography was $62 \mathrm{~mL}$, and post micturition residue was $40 \mathrm{~mL}$. Digital rectal examination revealed hypertrophic prostate (grade 2) and there was a small nodule in the left lobe. Results of some relevant laboratory tests were as follows: total prostate-specific antigen (PSA), $25.07 \mathrm{ng} / \mathrm{ml}$; free PSA, $2.01 \mathrm{ng} / \mathrm{ml}$; white blood cell $14.700 / \mathrm{mm}^{3}$, C-reactive protein 56 $\mathrm{mg} / \mathrm{dl}$ (normal range $0.01-5 \mathrm{mg} / \mathrm{dl}$ ), erythrocyte sedimentation rate $41 \mathrm{~mm} / \mathrm{h}$, and other blood chemistry test results were within normal limits. The patient's urine and blood cultures were negative. Urinalysis revealed 62 white blood cells and 19 red blood cells per microscopic field. Alpha-blocker therapy to relieve lower urinary tract symptoms, and oral ciprofloxacin treatment (500 mg twice a day) were initiated. But he came back to our hospital after 3 days with fever (body temperature, $38^{\circ} \mathrm{C}$ ), and the symptoms of epididiymo-orchitis. The patient's serum sample was tested by Brucella Wright agglutination test considering that the patient is dealing with livestock sector. Sample dilutions started from 1/10 for Wright agglutination test and patient's Wright agglutination test was positive at $1 / 640$ titer. There was no bacterial growth in blood, urine, and semen cultures. Therapy with oral doxycycline (100 mg every $12 \mathrm{~h}$ ) and rifampin $600 \mathrm{mg}$ (once in a day) was administered over 6 weeks. After 4 days of treatment patient's complaints were dramatically regressed. After the treatment erythrocyte sedimentation rate was normal, the white blood cell count had decreased to normal levels, and total PSA was $0.94 \mathrm{ng} / \mathrm{ml}$. The patient recovered well for the treatment of 14 days. One month after the cessation therapy, digital rectal examination and ultrasonographic control examination of prostate had showed hypertrophy without nodule. The patient was followed-up to 12 months and no relapse was observed.

\section{DISCUSSION}

Brucellosis is a multisystem disease that may present with a broad spectrum of clinical appearance.
The symptoms and clinical signs most commonly reported are fever, chills, fatigue, headache, arthralgia, malaise, sweating, myalgia, arthralgia, and weight loss ${ }^{2}$. Osteoarticular disease is the most common presentation and the reproductive system is the second most common site of brucellosis, but every organ and system of the body can be practically affected by brucellosis?

Patients who had atypical clinical features usually consult to clinics after the use of some antibiotics. This situation makes bacterial isolation from blood culture unfeasible, thus treatments are delayed and this allows the recurrences ${ }^{8}$. We also delayed the treatment due to nonspecific lower urinary tract symptoms till the development of clinical characteristics of epididymo-orchitis.

In our patient, we made the diagnosis based on the determination of $1 / 640$ titers at Wright agglutination tube test together with a negative blood culture. The World Health Organization (WHO) criteria for the diagnosis of brucellosis are detection of the symptoms combined with standard Brucellatube agglutination test of $\geq 1 / 160$ titers or bacterial growth in blood ${ }^{4}$. Bacterial growth was not detected in our standard urine and semen cultures. Routine urine or semen culture was generally used to exclude the presence of other microorganisms in Brucella epididymo-orchitis ${ }^{9}$.

Serum PSA elevations can be caused by prostate cancer, benign prostatic hyperplasia and prostatitis ${ }^{10}$. Moreover, unnecessary prostate biopsies are still a main issue. In our case, there was a nodule detected on digital rectal examination and total PSA was 25.07 $\mathrm{ng} / \mathrm{ml}$. As our case, brucella-induced prostatitis may be considered in the differential diagnosis of prostate cancer. In a similar case, Karabakan et al. ${ }^{11}$ took 10 prostate core needle biopsies from the patient before long. After the biopsy, the patient with high fever were admitted to the hospital and received intravenous antibiotic therapy. In endemic areas, elevated PSA values with the signs and symptoms of brucellosis should be taken into account and proper 
treatment should be initiated as soon as possible before resorting to invasive procedures.

Ciprofloxacin is not recommended as the first-line preference in the medical treatment of brucellosis ${ }^{12}$. In our case, the patient came back to our hospital with $38^{\circ} \mathrm{C}$ fever on the $3^{\text {rd }}$ day of ciprofloxacin treatment. World Health Organization recommends a 45 day course of oral doxycycline $200 \mathrm{mg} /$ day and streptomycin $1 \mathrm{~g} /$ day for the treatment of Brucella epididymo-orchitis. An alternative is a 45 day course of oral rifampicin $15 \mathrm{mg} / \mathrm{kg} /$ day (600-800 mg) and doxycycline $200 \mathrm{mg} /$ day $^{13}$. Alavi et al reported the overall failure rate of $7.4 \%$ (range, $2-10 \%$ and relapse rate of $4.8 \%$ (range, $0-9.7 \%$ ) with the combination of streptomycin plus doxycycline. They also showed the overall treatment failure and relapse rates in their review were $7.8 \%$ (range, $3.1-15 \%$ ) and $10.7 \%$ (range, $3.5-16 \%$ ), respectively with the combination of doxycycline plus rifampicin ${ }^{14}$.

In conclusion, acute prostatitis is a rare complication of brucellosis, with very scarce number of published reports $^{4-6}$. In endemic areas, it should not be forgotten that prostatitis may result from brucellosis and brucella prostatitis may mimic prostate carcinoma.

\section{Conflict of interest}

None declared.

\section{Funding}

The author(s) received no financial support for this study.

\section{REFERENCES}

1. Mert A, Ozaras R, Tabak F, et al. The sensitivity and specificity of Brucella agglutination tests. Diagn Microbiol Infect Dis. 2003;46:241-243. https://doi.org/10.1016/S0732-8893(03)00081-6

2. Franco MP, Mulder M, Gilman RH, Smits HL. Human brucellosis. Lancet Infect Dis 2007;7:775-786. https://doi.org/10.1016/S1473-3099(07)70286-4

3. Buzgan T, Karahocagil MK, Irmak H, et al. Clinical manifestations and complications in 1028 cases of brucellosis: a retrospective evaluation and review of the literature. Int J Infect Dis 2010;14:469-78.

https://doi.org/10.1016/j.ijid.2009.06.031

4. Rosales Leal JL, Tallada Bu-uel M, et al. Acute prostatitis as the 1st symptom of brucellosis. Arch Esp Urol 2003;56:527-529.

5. Aygen B, Sumerkan B, Doganay M, Sehmen E. Prostatitis and hepatitis due to Brucella melitensis: a case report. J Infect 1998;36:111-112. https://doi.org/10.1016/S0163-4453(98)93486-7

6. Hakko E, Ozdamar M, Turkoglu S, Calangu S. Acute prostatitis as an uncommon presentation of brucellosis. BMJ Case Rep 2009;12:1370.

https://doi.org/10.1136/bcr.12.2008.1370

7. Pappas G, Akritidis N, Bosilkovski M, Tsianos E. Brucellosis. N Engl J Med 2005;352:2325-2336. https://doi.org/10.1056/NEJMra050570

8. Senol S, Yamazhan T, Gökengin D. A seronegative case of brucellosis presenting with acute prostatitis. Klinik 2004;3:209-210.

9. Navarro-Martinez A, Solera J, Corredoira J, Beato JL, MartinezAlfaro E, Atienzar M, Ariza J. Epididymoorchitis due to Brucella melitensis: a retrospective study of 59 patients. Clin Infect Dis 2001;33:2017-2022. https://doi.org/10.1086/324489

10. Loeb S, Catalona WJ. What to do with an abnormal PSA test. Oncologist 2008;13:299-305. https://doi.org/10.1634/theoncologist.2007-0139

11. Karabakan M, Akdemir S, Akdemir AO, et al. A Rare Case of Prostatic Brucellosis Mimicking Prostate Cancer. Urol J 2014;11(6):1987-1988.

12. Ariza J, Bosilkovski M, Cascio A, Colmenero JD, Corbel MJ, Falagas ME, Memish ZA, Roushan MR, Rubinstein E, Sipsas NV et al. Perspectives for the treatment of brucellosis in the 21st century: the loannina recommendations. PLoS Med 2007;4:e317. https://doi.org/10.1371/journal.pmed.0040317

13. Brucellosis in human and animals. Geneva (Switzerland): World Health Organization; 2006.

14. Alavi SM, Alavi L. Treatment of brucellosis: a systematic review of studies in recent twenty years. Caspian J Intern Med 2013;4(2):636-641. 